\title{
Dysregulated Circulating micro RNAs Markers: New Evidence into Expression Pattern in Children with T1D among Egyptian Population
}

Naglaa Barseem ( $\sim$ naglaa_b2000@yahoo.com )

Menoufia University Faculty of Medicine https://orcid.org/0000-0003-3220-0237

Marwa Mahasab

Menoufia University Faculty of Medicine

Eman Abd El Gayed

Menoufia University Faculty of Medicine

Research article

Keywords: Type 1 Diabetes, miRNAs, Plasma, q RT PCR, Gene expression

Posted Date: July 23rd, 2020

DOI: https://doi.org/10.21203/rs.3.rs-39439/v1

License: (c) (i) This work is licensed under a Creative Commons Attribution 4.0 International License. Read Full License 


\section{Abstract \\ Background}

miRNAs are gaining access as promising markers for a variety of autoimmune disorders yet, deviations between individuals at risk or developed T1D remains to be thoroughly explored. We aimed to study the pattern of miRNA expression profiling in plasma obtained from patients with T1D and the matched control subjects.

\section{Methods}

Equally divided numbers of T1D patients (90) and healthy-matched control children (90) were analyzed for their expression profile of plasma miRNAs; miR-101-5p, 146-5p, 21-5p, miR-375, miR-126, and Let7a-5p by reverse transcriptase (RT-PCR) through quantitative real-time technique.

\section{Results}

The two studied groups were significantly different in respect to their biochemical parameters; FBG, 2hpp, and HbA1c levels (p\&lt; 0.05). Among the deregulated molecules, miR-101, miR-21 and-375 were highly expressed, whereas, miR-146-5p, miR-126, and miR-Let7a-5p showed significantly low levels of expression in patients compared to control subjects $(p<0.05)$. MiR-101, miR-146 was significantly correlated to the age at diagnosis of T1D and disease duration respectively. Furthermore, miR-126, -Let7a-5p showed a significant negative correlation with meanA1C values, the matter that was confined by multivariate analysis.

\section{Conclusion}

Dysregulation of the above mentioned micro RNAs pointed out to their pivotal role to be important biomarkers for T1D development.

\section{Background}

Type 1 diabetes mellitus (T1DM) is an autoimmune disorder characterized by destruction of pancreatic beta-cells by T-lymphocytes and macrophages [1]. The disease is usually diagnosed when over $80-90 \%$ of beta-cells have been destructed by the infiltrating immune system. T1DM development is a slow process providing a potentially long window of time in which it is possible to identify and theoretically treat individuals at risk [2, 3].

It's estimated that about 80,000 children develop the disease each year [4]. Microvascular complications of diabetes have a significant impact on the quality of life, morbidity, and mortality, posing a huge burden on the health care system. Diabetic nephropathy is a leading cause of end-stage renal disease (ESRD) and augments the risk of cardiovascular diseases (CVD). Diabetic retinopathy is the major cause of new blindness in adults.

Therefore, it is urgent to identify novel targets for treatment and to discover innovative noninvasive biomarkers to improve risk prediction, early diagnosis, and prognosis assessment [5].

Non-coding RNAs including microRNAs (miRNAs) play an important role in the pathogenesis of T1D. miRNAs are short ( 22 nucleotides) non-coding RNAs that regulate gene expression in a posttranscriptional manner [6]. In 
general, the miRNAs exert their functions via binding with the 3 ' untranslated regions (UTRs) of their target genes, resulting in translational inhibition or direct degradation of the targeted mRNA leading to diminished protein expression [6, 7]. Alterations in miRNA expression have been associated with several human autoimmune and inflammatory diseases including T1D [8, 9].

MiRNAs regulate the expression of more than $60 \%$ of protein-coding genes; consequently, changes in their expressions have been linked to many diseases, including cancer, endocrine disorders, and autoimmune diseases [10].

MiRNA-specific profiles were observed in PBMCs or serum from T1DM patients, and some miRNAs seem to modulate mRNA expressions of the major T1DM autoantigens [11].On considering these aspects, the present study aimed to investigate the variable pattern of miRNA expression profiling in plasma obtained from patients with T1D and the matched control subjects through quantitative real-time PCR.

\section{Methods}

This case-control study was prospectively conducted on 90 children with T1D, with a mean age of (10.93 \pm 4.51 years) having variable disease duration and variable degrees of glycemic control, who were diagnosed according to ADA criteria (Group I) [1].

A group of apparently healthy age and sex-matched 90children were served as controls (Group II) with a mean age of (10.15 \pm 2.56 years). All were enrolled from the Pediatric Department in collaboration with the Department of Medical Biochemistry and Molecular Biology, Faculty of Medicine, Menoufia University Hospitals, Egypt. Collection of demographic data, anthropometric measurements, treatment regimens, and other clinical important parameters were done through viewing the medical sheet records for all sharing participants.

Cases who were suspected of not diagnosed as T1D; MODY, T2D, or secondary diabetes mellitus, or with evidence of chronic systemic/rheumatic diseases, inflammatory disorders, recent febrile illness, or on long-term steroid therapy were excluded from the study.

Upon approval of the study protocol from the Ethical Committee of Menoufia University per Helsinki II Declaration criteria, written informed consent was obtained from all participants in the study.

Following complete history taking \&amp; thorough clinical examination, all studied subjects underwent sampling of 7-10 ml whole blood after $12 \mathrm{~h}$ overnight fasting via sterile techniques and divided into tubes as;

One $\mathrm{ml}$ of blood was transferred into sodium fluoride tube and another sample of blood was obtained after 2 hours for enzymatic colorimetric determination of blood glucose measured by the enzymatic colorimetric test, using Spinreact kit, SPAIN [12].

Another $4 \mathrm{ml}$ of blood was transferred into two EDTA tubes: one of them was used for quantitative colorimetric determination of glycated hemoglobin expressed as a percentage of the total hemoglobin by the use of kits supplemented by Teco diagnostics, USA [13]. Glycated hemoglobin (HbA1c) values $\geq 6.5 \%$ were the limits for diagnosing T1DM [1].

The other EDTA tube was used for the extract of micro RNA molecules. 
-For molecular analysis, $2 \mathrm{ml}$ of blood was transferred into one EDTA-containing tube and centrifuged for ten minutes at (4000) r.p.m. The clear supernatant was separated and kept frozen at $-80^{\circ} \mathrm{C}$ until a further determination of MicroRNA levels.

\section{RNA isolation}

A total RNA including also miRNA molecules were purely extracted from plasma using Qiagen ${ }^{\text {TM }}$ RNA Blood Mini Kit (Qiagen, USA, 2013) as defined by the manufacturer's instructions.

\section{Reverse transcriptase PCR (RT-PCR):}

RNA was reversely transcribed through Qiagen® miScript II RT Kit (Qiagen, Applied Biosystems, USA, 2012), reaching to $50 \mathrm{ml}$ reaction volume. The obtained complementary (c DNA) was then assayed with the universal SYBR Green Master Mix (QuantiTect SYBR Green PCR Kit, Qiagen).

For preparing RT Master Mix: $4 \mu$ l 5×miScript HiSpec Buffer, $2 \mu l$ 10×miScript Nuclease Mix, $2 \mu$ l RNase-free water, $2 \mu \mathrm{l}$ miScript Reverse Transcriptase Mix, then a $10 \mu \mathrm{l}$ Template RNA

to reach a total reaction volume $20 \mu \mathrm{l}$. Reverse transcription was carried out at $37^{\circ} \mathrm{C}$ for 60 minutes and $95^{\circ} \mathrm{C}$ for 5 minutes on Applied Biosystems 2720 thermal cycler (Bioline, Singapore, USA) c DNA product was diluted to 5 $\mathrm{ng} / \mathrm{ul}$ for the measurement of transcript levels by real-time quantitative PCR. Diluted c DNA was used as the template for real-time PCR with the miScript SYBR Green PCR Kit produced by Qiagen. Adding universal Primers was based on mRNA sequences delivered from the miR-Base database for (mi RNA 101-5p, mi RNA 146a-5p, mi RNA- 375, mi RNA 21-5p, miR 126, and miR

Let 7 a-5p) as shown in Table (1a). Each reaction for real-time PCR was completed to a final $25 \mu \mathrm{L}$ volume, as followed: $12.5 \mu \mathrm{l}$ 2x QuantiTect SYBR Green PCR Master Mix, $2.5 \mu \mathrm{l}$ 10x miScript specific Primer, $2.5 \mu \mathrm{l}$ 10x miScript primer assay, $4 \mu \mathrm{l}$ Template c DNA and 3.5 $\mu$ RNase-free water. the mixture was incubated at these conditions: $95^{\circ} \mathrm{C}$ for $15 \mathrm{~min}$ (as initial denaturation), then denaturation at $94^{\circ} \mathrm{C}$ for $15 \mathrm{~s}$ duration, annealing for $30 \mathrm{~s}$ at a temperature of $55^{\circ} \mathrm{C}$ and final extension for $30 \mathrm{~s}$ adjusted at $70^{\circ} \mathrm{C}$, for designed 60 cycles. Amplification of small RNA RNU6B was performed with each experimental sample as an endogenous control. Data analysis was done in the real-time cycler Applied Biosystems ${ }^{\circledR} 7500$ software version 2.0.1 thermal cycler (Applied Biosystems, Foster City, CA, USA).

The relative quantification (RQ) of genes expression was performed by comparative $\Delta \Delta \mathrm{Ct}$ method, in which the amount of targeted mi RNAs 101-5p, mi RNA146a-5p, mi RNA-375, mi RNA21-5p, mi RNA 126, and mi RNA Let 7 a-5p were normalized to RNU6B as an endogenous reference among patients and controls.

\section{Table (1a): Primers used for the quantitative RT-q PCR assay for micro-RNA determination in all samples.}




\begin{tabular}{|c|c|c|c|}
\hline $\begin{array}{l}\text { Mature } \\
\text { mi } \\
\text { RNA } \\
\text { symbol }\end{array}$ & Accession No. & Sequence & Catalogue No. \\
\hline $\begin{array}{l}\text { miR } \\
101-5 p\end{array}$ & MIMAT0004513 & 5-CAGUUAUCACAGUGCUGAUGCU-3 & MS00008379 \\
\hline $\begin{array}{l}\operatorname{miR} \\
146 \text { a- } \\
5 p\end{array}$ & MIMAT0000449 & 5-UGAGAACUGAAUUCCAUGGGUU-3 & MS00003535 \\
\hline $\begin{array}{l}\operatorname{miR} 21 \\
a-5 p\end{array}$ & MIMAT0004494 & 5-CAACACCAGUCGAUGGGCUGU-3 & MS000009086 \\
\hline $\begin{array}{c}\mathrm{miR} \\
-375\end{array}$ & MIMAT00000728 & 5-UUUGUUCGUUCGGCUCCGUGA-3 & MS000031829 \\
\hline $\begin{array}{l}\operatorname{miR} \\
126 \text { a- } \\
3 p\end{array}$ & MIMAT0000445 & 5-UCGUACCGUGAGUAAUAAUGCG-3 & MS00003430 \\
\hline $\begin{array}{l}\text { Let } 7 a- \\
5 p\end{array}$ & MIMAT0000062 & 5-UGAGGUAGUAGGUUGUACAGUU-3 & MS00031220 \\
\hline RNU6B & Internal control & $\begin{array}{l}\text { 5- } \\
\text { CGCAAGGATGACACGCAAATTCGTGAAGCGTTCCATATTTTT- } \\
3\end{array}$ & MS00033740 \\
\hline
\end{tabular}

\section{Statistical analysis:}

Data were analyzed using IBM SPSS statistics version 20 (SPSS Inc., Chicago, USA). Quantitative data were expressed as mean and standard deviation. A Chi-square test was used to examine the relation between qualitative variables. For quantitative data, a comparison between the two groups was done using either student ttest or Mann-Whitney test (non-parametric t-test) as appropriate. Spearman's correlation method was used to test the correlation between numerical variables. For the determination of T1D risk, multivariate logistic regression analysis was additionally used aided by the calculation of odds ratio (OR) and 95\% Confidence Interval (Cl). A pvalue $\leq 0.05$ was considered significant.

\section{Results}

In this study, a total of 180 children, including 90[46 males and 44 females] children with T1D (Group I), and healthy age and gender-matched 90 [55 males and 35 females] control subjects (Group II) were investigated for the expression pattern for the circulating mi-RNAs-101, 146, Let-7a, 21-5p, -375, and 126-5p molecules.

Their ages ranged from 10.93(4.51) for T1D patients and 10.15(2.56) for the control group. The demographic and clinical data of the studied groups were shown in (Table 1).

Results of laboratory investigations for the group of T1D children including biochemical indices of; FBG, 2 h-PP, and mean $\mathrm{HbA} 1 \mathrm{C} \%$ were found to be statistically significant in comparison to controls (t-test: $23.985,23.156$ and $14.165, \mathrm{P}<0.0001$ ) in order. All of the newly diagnosed cases with T1D disease duration, not more than612 months were chosen as being positive for anti-insulin autoantibodies (IAAs), that ranged from 1 0-130 mIU/L 
with mean value $10.42 \pm 19.59$ in those cases and from $0-7.0 \mathrm{mIU} / \mathrm{L}$ with mean value $2.08 \pm 2.36$ in healthy control children(U:7.03, P:0.002).

Comparative results regarding the levels of micro-RNAs studied in both groups revealed that miR-101-5p, miR-21$5 p$, miR 375 were highly expressed in patients with T1D, with a difference of statistical significance $(P<0.05)$, whereas miR146-5p, miR 126, and miR Let 7a-5p showed down-regulation of their plasma levels $(p-v a l u e<0.05)$ in order (Table 2). Of the remarkable findings in this study was that our results indicated a significant negative correlation of miR 101-5p with the age of onset $(r=-0.264, p=0.015)$ and with the duration of illness of T1D $(r=-0.162, p=0.02)$ in respect. MiR-146 was correlated with T1D disease duration $(r=0.239, p=0.023)$. On the other hand, miR 126, and miR-Let7a-5p were significantly negatively correlated to mean T1D patients ' glycated Hb A1c levels; $p$ value $<0.05$ (Table 3).

Results of multivariate logistic regression analysis for T1D risk were shown in (Table 4), where miR126-5p and miR-Let7a- markers showed highly significant findings after adjustment of values for age, sex and mean $\mathrm{Hb} \mathrm{A} 1 \mathrm{C}$ levels in patients group as evidenced by Odds ratio, $\mathrm{Cl} 95 \%$ of $0.016(0.0-0.544), \mathrm{p}=0.021$ for $-126-5 \mathrm{p}$ and $1.808(1.006-3.249)$ and $p$ value $=0.048$ for mi-Let7a- in order.

Correlations between mi-RNAs101-5p, 126-5p, and certain diabetes parameters were shown in Figs. 1, 2.

The Amplification for micro-RNAs expression pattern (normalized fluorescent signal $[\Delta \mathrm{Rn}]$ that was plotted against the number of cycles) was evident in figures from 3-8 in the corresponding sequence.

\section{Discussion}

The emerging role of miRNAs in modulating gene expression has greatly developed and is being recently implicated in the presentation of different diseases [14-16]. Validity Reliability in the level of expression of these circulating molecules favored the extreme ability to be recognized as key biomarkers of disease pathogenesis and progression status $[17,18]$. This was evidenced by the relation of these molecules to $60 \%$ or more of the coding genes that thought to be in linkage to various endocrinal and autoimmune diseases [19-21].

Based on the underlying autoimmune background of T1D, our studied cases with recent disease onset; not more than6-12months duration; were chosen upon their positivity for insulin autoantibodies, the matter that researchers related certain miRNAs molecules to be validated as newly developed markers at early phases. Although for some, the progressive pattern in at-risk individuals couldn't be addressed, still several miRNAs are tightly associated with both glucose homeostasis and levels of autoantibodies to be the cornerstone in risk stratification [22].

In the issue of T1D, it's not still clearly understood whether the miRNAs have a cornerstone step in T1D pathogenesis or merely markers of active B cell dysfunctional outcome [23]. Butz et al reported a pivotal effect of mi- RNAs on pancreatic cellular biology, especially for B-cell differentiation, production of insulin, apoptosis, and mediation of inflammation [24].

In our study, among the analyzed mi RNAs, miR-146a-5p, Let-7a, and miR-126 were found to be down-regulated, whereas miR-101, 21-5p, and miR375a-5p were consistently up-regulated in patients when compared to our control subjects. 
As for miR-375, its extreme abundance in pancreatic tissue rendered it a reflection of B-cell mass and alterations in its metabolic functions [25]. In respect to our results, it was found that the level of miR-375 in the plasma of patients with T1D was significantly increased. When globally analyzed for its correlation to HbA1C, no difference was noticed as evidenced by a coefficient r-value of 0.173 and a p-value of 0.201 . The relation of that molecule to meanA1C values was favored by Marchand et al., 2016 who found dysregulated miR-375 level in the blood of newly diagnosed children with type 1diabetes when quantified to high levels in human islet tissue, the matter that conferred that to be a hallmark in the etiology of T1D. Furthermore, it may be a marker of the early phases of the disease [26].

Of the deregulated molecules in our study that was found to be up-regulated in the group of T1D patients versus those of control subjects as a difference of statistical significance ( $p$ value $<0.001$, Table 2) was 21-5p, which was examined by Pan et al., for the involvement of enteroviral infection on 21-5p expression and subsequent contribution to T1D [27].

Analyzing data from past literature, revealed that has-miR-21seemed to be highly expressed in plasma of T1D patients in comparison to controls. Osipova et al., 2014 [28] found similar results. Ongoing research related 21-5p to cytokines of inflammation. In addition to the findings of Backe and coworkers [29], it was suggested that miR21 overexpression was believed to influence the Bax group/ apoptotic signaling pathway, hence inducing pancreatic B-cell death. This process could be served as a new therapeutically tried target for T1DM [30, 31].

Another up-regulated miRNA in our study was - 101-5p, that targeted reduction of insulin secretion and B-cell mass as a favor of its involvement in cytokine release regulation and altered signaling of STAT3, HGF/C-Met and Ephrin receptors pathway mechanisms. Adjuvant to our findings of the significant association of miR101-5p to insulin autoantibody-positive cases of recent onset T1D with disease duration, not more than 6-12 months, this matter that was largely analyzed by Santos A et al., who reported that the expression of miR-101 was about $3 f$ fold higher in patients with multiple autoantibodies level[32].

As found in our study, the negative correlation of miR-101 with the age of onset of T1D $(r=-0.264, p=0.015)$, related studies suggested a greater rate of B-cell turnover and pancreatic injury in young children with T1DM [33, 34].

Another important micro-RNA molecule that showed significant down regulation besides being indicated in patients with recent-onset T1D was the miR146 a-5p. This was evident through a lowered expression level in cases; median (IQR) of 0.16(0.02-0.43) compared to levels of $0.77(0.0-0.88)$ in control subjects $(p<0.001)$. A possible biological effect explored from its consistent relation to genes linked to apoptotic and innate immune regulatory pathway mechanisms [35].

Let7 a-5p was one of the studied markers expressed at lower levels in the studied group of patients and demonstrated a statistically significant difference in comparison to that of controls. Similar results were evident in the study done by Tian $\mathrm{C}$ et a., where Let - 7a was down-regulated in both human and mice tissue derivatives [36]. The later was known to be involved in the regulation of glucose metabolism. In agreement with our results, it was found to be negatively correlated to A1C by the study done by Erener et al., 2017 [37].

Assessing the level of miR-126expression revealed contradictory findings. Osipova et al., conducted lower urinary levels in patients with T1D, with no significant difference in plasma samples of the studied cases and controls respectively [28]. However, the observation of Wang et al. clarified decreased plasma levels of miR-126 in those 
with chronic ESRD [38]. Despite the disagreeable findings identified in our study about the significant lower plasma level of the miR-126 in T1D patients to that of Osipova et al., they came in the same line with the proposed mechanism that related decreased level of miR-126 to deranged response to vascular endothelial growth factor (VEGF) and endothelial dysfunction [28, 39, 40]. Also, previous reports considered this marker as a controlling factor for various biological processes [41, 43], through linkage of decreased circulatory miR-126 levels to microvascular change and possibility of later-on long-standing T1DM complications [43]. The noticed significant negative correlation between miR-126, mi-R Let7a- markers, and high percentages of the mean $\mathrm{HbA} 1 \mathrm{C}$ values suggested the significant association of hyperglycemia to of the altered levels of the circulating miRNAs to hyperglycemic state [37]. These above considerations were nearly similar to the hypothesis of Akerman et al., 2018 who assumed that expression profiling of miRNAs may be of value regarding their feasibility to be a distinguishing complementary marker in risky individuals with abnormal OGTT results [22].

\section{Conclusion}

Deregulation of microRNAs in our study revealed down-regulation of miRNAs 146-5p, 126-5p and Let 7a-5p molecules and the up-regulation of miR101-5p, 21-5p and 375- were identified in our study for their significant relation toT1DM. The additional significant negative correlation of miR126-5p and Let7a-5p micro RNAs with mean glycated $\mathrm{HbA} 1 \mathrm{C}$ values are indicative of possible use as biomarkers hyperglycemia-associated pathophysiologic changes in T1DM.

Given the stability, reliability of these markers, they were preferred for their superiority over other quantification techniques establishment through q-RT-PCR and warranted our choice in that study to be the 1st estimate for micro-RNA profiling among Egyptian children having type1diabete, the matter that potentiates pavement of the way to their targeted usage as new intervention therapeutic markers. Of course, further larger-scale functional studies are required for genetic interactions thus improving the quality and life expectancy of children with T1DM.

\section{Abbreviations}

Cl

Confidence Interval.

\section{CVD}

Cardiovascular diseases

\section{ESRD}

End-stage renal disease

\section{HbA1c}

Hemoglobin A1C.

\section{Mi RNA}

Micro ribonucleic acid.

\section{OGTT}

Oral glucose tolerance test.

\section{OR}

Odds ratio.

\section{PBMCs}

Peripheral blood mononuclear cells. 
PCR

Polymerase chain reaction.

Q-RT- PCR

Quantification techniques- Polymerase chain reaction.

RQ

Relative quantification

RT

Reverse transcriptase.

T1DM

Type 1 diabetes mellitus.

UTRs

Untranslated regions.

\section{Declarations}

\section{Acknowledgements}

Not applicable.

\section{Authors' contributions}

NFB designed the study, analyzed data and drafted the manuscript MMM and EMA participated in the design of the study and coordination of the whole work. NFB and MMM collected and organized patients' data. NFB and EMA performed molecular genetic studies for patients. NFB and MMM analyzed the data. All authors have read and approved the manuscript and ensure that this is the case.

\section{Funding:}

None.

\section{Availability of data and material:}

The datasets are available from the corresponding author on reasonable request.

\section{Ethics approval and consent to participate:}

All procedures performed in studies involving human participants were in accordance with ethical standards of the institutional review committee of Huang et al. BMC Endocrine Disorders (2020) 20:99 Page 7 of 9 the Third Affiliated Hospital of Soochow University and with the 1964 Helsinki declaration and its later amendments or comparable ethical standards. The present study was approved by the Institutional Review Committee of the Faculty of Medicine, Menoufia University.

All subjects gave written, informed consent through their parent or guardian before enrollment in the study.

\section{Consent for publication:}

Not applicable. 
Competing interests:

The authors declare that they have no competing interests.

\section{References}

1- American Diabetes Association. Classification and diagnosis of diabetes. Diabetes Care 2015. 38 S8-S16. (10.2337/dc15-S005) [PubMed] [CrossRef]

2- Guay C, Regazzi R. Circulating microRNAs as novel biomarkers for diabetes mellitus. Nature Reviews Endocrinology 2013. 9 513-521. (10.1038/nrendo.2013.86) [PubMed] [CrossRef]

3- Atkinson MA, Eisenbarth GS. Type 1 diabetes: new perspectives on disease pathogenesis and treatment. Lancet 2001. 358 221-229. (10.1016/S0140-6736(01)05415-0) [PubMed] [CrossRef].

4- Shujuan Liu, Haixia Li. Down-regulation of microRNA-28 in peripheral blood mononuclear cell plays a role in pathogenesis of type 1 diabetes. Int J Clin Exp Med 2017;10 (7):10021-10030

5- Barutta F, Bellini S, Mastrocola R , Bruno G, and Gruden G. MicroRNA and Micro-vascular Complications of Diabetes.(2018); International Journal of Endocrinology, https://doi.org/10.1155/2018/6890501.

6-Simranjeet Kaur, Flemming Pociot.(2018); miRNAs regulate development and function of regulatory T-cells in recent onset islet autoimmunity in pre-Type 1 diabetes. doi: 10.21037/ncri.2018.03.06.

7- Lewis BP, Burge CB, Bartel DP. Conserved seed pairing, often flanked by adenosines, indicates that thousands of human genes are microRNA targets. Cell 2005; 120:15-20.

8- Sebastiani G, Spagnuolo I, Patti A, et al. MicroRNA expression fingerprint in serum of type 1 diabetic patients. Diabetologia. 2012; 55:S48.

9- Nielsen LB, Wang C, Sørensen K, et al. Circulating levels of microRNA from children with newly diagnosed type 1diabetes and healthy controls: evidence that miR-25 associates to residual beta-cell function and glycaemic control during disease progression. Exp Diabetes Res. 2012:896362.

10- Lin S \& Gregory RI. MicroRNA biogenesis pathways in cancer. Nature Reviews Cancer (2015) 321-333. (doi:10.1038/nrc3932).

11-Abuhatzira L, Xu H, Tahhan G, Boulougoura A et al. Multiple microRNAs within the 14q32 cluster target the mRNAs of major type 1 diabetes autoantigens IA-2, IA-2beta, and GAD65. FASEB Journal (2015) 29 4374-4383. (doi:10.1096/fj.15-273649).

12-Trinder P: Determination of glucose in blood using glucose oxidase with an alternative oxygen acceptor. J Ann Clin Biochem(1969); 6: 24-25.

13-Gonen B and Rubenstien AH: Determination of glycohemoglobin. Diabetologia (1978); 15:1-5.

14- Ardekani AM and Naeini M: The role of microRNAs in human diseases. Avicenna J Med Biotechnol 2: 161-179, 2010. 
15- Pandey AK, Agarwal P, Kaur K and Datta M: MicroRNAs in diabetes: Tiny players in big disease. Cell Physiol Biochem 23: 221-232, 2009.

16- Bhatt K, Mi QS and Dong Z: MicroRNAs in kidneys: Biogenesis, regulation, and pathophysiological roles. Am J Physiol Renal Physiol 300: F602-F610, 2011.

17- Butz H, Kinga N, Racz K \& Patocs A. Circulating miRNAs as biomarkers for endocrine disorders. Journal of Endocrinological Investigation 201639 1-10. (doi:10.1007/s40618-015-0316-5)

18- Carrington JC \& Ambros V. Role of microRNAs in plant and animal development. Science 2003 301 336-338. (doi:10.1126/ science.1085242)

19- Lin S \& Gregory RI. MicroRNA biogenesis pathways in cancer. Nature Reviews Cancer 2015 15 321-333. (doi:10.1038/nrc3932)

20- Pauley KM, Cha S \& Chan EK. MicroRNA in autoimmunity and autoimmune diseases. Journal of Autoimmunity 200932 189-194. (doi:10.1016/j.jaut.2009.02.012)

21-Zalts H \& Shomron N. The impact of microRNAs on endocrinology. Pediatric Endocrinology Reviews 20118 354-362.

22-Akerman L, Casas R, Ludvigsson J, Tavira B, Skoglund C. Serum miRNA levels are related to glucose homeostasis and islet autoantibodies in

children with high risk for type 1 diabetes. PLoS ONE 13(1): e0191067. https://doi.

org/10.1371/journal.pone.0191067

23- Esteller M. Non-coding RNAs in human disease. Nature Reviews Genetics 201112 861-874.

(doi:10.1038/nrg3074).

24- Butz H, Kinga N, Racz K \& Patocs A. Circulating miRNAs as biomarkers for endocrine disorders. Journal of Endocrinological Investigation 201639 1-10. (doi:10.1007/s40618-015-0316-5)

25- M. van de Bunt, K. J. Gaulton , L. Pfarts et al., "The miRNA profile of human pancreatic islets and beta-cells and relationship to type 2 diabetes pathogenesis," PLoS ONE, vol. 8, no. 1, article e55272, 2013.

26- Marchand L, Jalabert A, Meugnier E, Vanden K, Fabien N, Nicolino M, Madec A.M., Thivolet C and Kone S: MiRNA-375 a Sensor of Glucotoxicity Is Altered in the Serum of Children With Newly Diagnosed Type1Diabetes. Journal of Diabetes Research. http://doi.org/ 10.1155/2016/1869082.

27- Pan W, Zhu S, Yuan M, Cui H, Wang L, Luo X, Li J, Zhou H, Tang Y \& Shen N. MicroRNA-21 and microRNA-148a contribute to DNA hypomethylation in lupus CD4+ T cells by directly and indirectly targeting DNA methyl transferase 1. Open Journal of Immunology 2010184 6773-6781. (doi:10.4049/jimmunol.0904060)

28- Osipova J, Fischer DC, Dangwal S, Volkmann I, Widera C, Schwarz K, Lorenzen JM, Schreiver C, Jacoby U, Heimhalt M, Thum T, Haffner D. Diabetes-associated microRNAs in pediatric patients with type 1 diabetes mellitus: a cross-sectional cohort study. J Clin Endocrinol Metab. 2014; 99(9):E1661-5. 
29- Backe MB, Novotny GW, Christensen DP, Grunnet LG \& Mandrup- Poulsen T. Altering beta-cell number through stable alteration of miR-21 and miR-34a expression. Islets 20146 e27754. (doi:10.4161/ isl.27754)

30-Sheedy FJ, Palsson-McDermott E, Hennessy EJ, Martin C, O'Leary JJ, Ruan Q, Johnson DS, Chen Y \& O'Neill LA. Negative regulation of TLR4 via targeting of the proinflammatory tumor suppressor PDCD4 by the microRNA miR21. Nature Immunology 201011 141-147. (doi:10.1038/ni.1828).

31-Ventriglia G, Nigi L, Sebastiani G \& Dotta F. MicroRNAs: novel players in the dialogue between pancreatic islets and immune system in autoimmune diabetes. BioMed Research International 20152015749734.

32-Santos A, Cunha N, Fukui R, Ferreira R.P, and Silva M: Increased expression of circulatory micro RNA101-in Type1Diabetes Patients: New Insights Into miRNA-Regulated Pathophysiological Pathways for Type1Diabetes. Frontiers in Immunology, (2019). Doi: 10.3389/ Fimmu. 2019.01637.

33-Kassem S, Ariel I, Thornton P, Scheimberg I, Glaser B: Beta cell proliferation and apoptosis in the developing normal human pancreas and in hyperinsulinism of infancy. Diabetes (2000). 49:1325-33.doi: 10.2337/ diabetes.49.8.1325.

34- Tugay K, Guay C, Marques A, Allagnat F, Locke J, Harries L W, et al.:Role of micro RNA in the age-associated decline of pancreatic beta cell function in rat islets. Diabetologia. (2016) 59:161-9. doi: 10.1007/s00125-015-3783.

35- Lu LF, Boldin MP, Chaudhry A, Lin LL, Taganov KD, Hanada T, Yoshimura A, Baltimore D \& Rudensky AY. Function of miR-146a in controlling Treg cell-mediated regulation of Th1 responses. Cell 2010 142 914-929. (doi:10.1016/j.cell.2010.08.012)

36- Tian C, Ouyang X, Lv Q, Zhang Y \& Xie W. Cross-talks between microRNAs and mRNAs in pancreatic tissues of streptozotocin-induced type 1 diabetic mice. Biomedical Reports 20153 333-342.

37- Erener S, Marwaha A, Tan R, Panagiotopoulos C, Kieffer TJ. Profiling of circulating microRNAs in children with recent onset of type 1 diabetes. JCI Insight. 2017; 2(4):e89656.

38- Wang H, Peng W, Shen X, Huang Y, Ouyang X and Dai Y: Circulating levels of inflammation-associated miR-155 and endothelial-enriched miR-126 in patients with end-stage renal disease. Braz J Med Biol Res 45: 1308-1314, 2012.

39- Harris TA, Yamakuchi M, Ferlito M, Mendell JT and Lowenstein CJ: MicroRNA-126 regulates endothelial expression of vascular cell adhesion molecule 1. Proc Natl Acad Sci USA 105: 1516-1521, 2008.

40- Jiang Y, Wang HY, Li Y, Guo SH, Zhang L and Cai JH: Peripheral blood miRNAs as a biomarker for chronic cardiovascular diseases. Sci Rep 4: 5026, 2014.

41-Bartel DP: MicroRNAs: Target recognition and regulatory functions. Cell 136: 215-233, 2009.

42- Zampetaki A, Kiechl S, Drozdov I, Willeit P, Mayr U, Prokopi M, Mayr A, Weger S, Oberhollenzer F, Bonora E, et al: Plasma microRNA profiling reveals loss of endothelial miR-126 and other microRNAs in type 2 diabetes. Circ Res 107: 810-817, 2010. 
43- Bijkerk R, Duijs JM, Khairoun M, Ter Horst CJ, van der Pol P, Mallat MJ, Rotmans JI, de Vries AP, de Koning EJ, de Fijter JW, et al: Circulating microRNAs associate with diabetic nephropathy and systemic microvascular damage and normalize after simultaneous pancreas-kidney transplantation. Am J Transplant 15: 1081-1090, 2015.

\section{Tables}

Table (1): Comparison between the two studied group as regarding to demographic, clinical and laboratory data. 


\begin{tabular}{|c|c|c|c|c|c|c|}
\hline & \multicolumn{2}{|c|}{$\begin{array}{l}\text { T1DM } \\
(\mathrm{n}=90)\end{array}$} & \multicolumn{2}{|c|}{$\begin{array}{l}\text { Control } \\
(\mathrm{n}=90)\end{array}$} & \multirow[t]{2}{*}{$\begin{array}{l}\text { Test of } \\
\text { sig. }\end{array}$} & \multirow[t]{2}{*}{$P$} \\
\hline & No. & $\%$ & No. & $\%$ & & \\
\hline le & 46 & 48.1 & $\begin{array}{l}55 \\
35\end{array}$ & $\begin{array}{l}61.1 \\
38.9\end{array}$ & $\begin{array}{l}c^{2}= \\
1.827\end{array}$ & 0.176 \\
\hline $\begin{array}{l}\text { Inguinity } \\
\text { itive } \\
\text { rative }\end{array}$ & $\begin{array}{l}48 \\
52\end{array}$ & $\begin{array}{l}48 \\
52\end{array}$ & 65 & 65 & $2 . c$ & 0.006 \\
\hline $\begin{array}{l}\text { y history } \\
\text { itive } \\
\text { gative }\end{array}$ & 21 & 21 & $\begin{array}{l}0 \\
100\end{array}$ & $\begin{array}{l}0 \\
100\end{array}$ & $20.1^{*}$ & $<0.001^{*}$ \\
\hline $\begin{array}{l}\text { vears) } \\
\pm \mathrm{SD}\end{array}$ & \multicolumn{2}{|c|}{$10.93 \pm 4.51$} & \multicolumn{2}{|c|}{$10.15 \pm 2.56$} & $\begin{array}{l}\mathrm{t}= \\
1.434\end{array}$ & 0.154 \\
\hline $\begin{array}{l}\text { ic blood pressure }(\mathrm{mm} / \mathrm{hg}) \\
\text { an } \pm \text { SD. }\end{array}$ & \multicolumn{2}{|c|}{$107.4 \pm 6.10$} & \multicolumn{2}{|c|}{$110.0 \pm 4.50$} & $\begin{array}{l}t= \\
3.199^{*}\end{array}$ & $0.002^{*}$ \\
\hline $\begin{array}{l}\text { Jlic blood pressure }(\mathrm{mm} / \mathrm{hg}) \\
1 \pm \mathrm{SD} \text {. }\end{array}$ & \multicolumn{2}{|c|}{$67.78 \pm 5.95$} & \multicolumn{2}{|c|}{$67.0 \pm 6.44$} & $\begin{array}{l}t= \\
0.841\end{array}$ & 0.401 \\
\hline $\begin{array}{l}\text { KG/M2) } \\
\text { n(SD) } \\
\text { ge }\end{array}$ & \multicolumn{2}{|c|}{$19.6 \pm 3.98$} & \multicolumn{2}{|c|}{$20.22 \pm 5.51$} & $t=0.91$ & 0.32 \\
\hline $\begin{array}{l}\text { f onset } \\
\pm \text { SD. } \\
\text { In (IQR) }\end{array}$ & \multicolumn{2}{|c|}{$\begin{array}{l}6.93 \pm 3.29 \\
7.0(5.0-10.0)\end{array}$} & & & & \\
\hline $\begin{array}{l}\text { ion of illness } \\
\pm \mathrm{SD} \text {. } \\
\text { In (IQR) }\end{array}$ & \multicolumn{2}{|c|}{$\begin{array}{l}4.41 \pm 3.35 \\
4.42(1.0-7.0)\end{array}$} & & & & \\
\hline$\overline{\text { ntation }}$ & $\begin{array}{l}30 \\
60\end{array}$ & $\begin{array}{l}33.3 \\
66.7\end{array}$ & & & & \\
\hline $\mathrm{C} \%$ & & & & & $t=$ & $<0.001^{*}$ \\
\hline
\end{tabular}




\begin{tabular}{|c|c|c|c|c|c|c|}
\hline $\begin{array}{l}\text { san } \pm \text { SD } \\
\text { ədian (IQR) }\end{array}$ & \multicolumn{2}{|c|}{$\begin{array}{l}9.03 \pm 2.04 \\
9.0(7.2-10.0)\end{array}$} & \multicolumn{2}{|c|}{$\mid \begin{array}{l}5.94 \pm 0.34 \\
5.95(5.7-6.2)\end{array}$} & $14.165^{*}$ & \\
\hline \multicolumn{7}{|l|}{$\mathrm{ng} / \mathrm{dl})$} \\
\hline ı. - Max. & \multicolumn{2}{|c|}{$105.0-300.0$} & \multicolumn{2}{|c|}{$75.0-105.0$} & \multirow{3}{*}{$\begin{array}{l}\mathrm{t}= \\
23.985^{*}\end{array}$} & \multirow[t]{3}{*}{$<0.001^{*}$} \\
\hline æn \pm SD. & \multirow{2}{*}{\multicolumn{2}{|c|}{$\begin{array}{l}210.52 \pm 46.46 \\
200.0(180.0-250.0)\end{array}$}} & \multirow{2}{*}{\multicolumn{2}{|c|}{$\begin{array}{l}91.0 \pm 8.76 \\
91.0(85.0-98.0)\end{array}$}} & & \\
\hline $\operatorname{dian}(\mathrm{IQR})$ & & & & & & \\
\hline \multicolumn{7}{|l|}{$\mathrm{P}(\mathrm{mg} / \mathrm{dl})$} \\
\hline ı. - Max. & \multicolumn{2}{|c|}{$130.0-310.0$} & \multicolumn{2}{|c|}{$140.0-172.0$} & \multirow{3}{*}{$\begin{array}{l}t= \\
23.156^{*}\end{array}$} & \multirow[t]{3}{*}{$<0.001^{*}$} \\
\hline æn \pm SD. & 257 & 40.31 & 154. & \pm 11.47 & & \\
\hline $\operatorname{dian}(\mathrm{IQR})$ & \multicolumn{2}{|c|}{$260.0(220.0-300.0)$} & 155. & $45.0-165.0)$ & & \\
\hline \multirow[t]{3}{*}{, albuminuria } & & & & & & \\
\hline & 82 & 91.1 & 91 & 100.0 & $c^{2}=$ & $F E_{p=}$ \\
\hline & 8 & 8.9 & 0 & 0.0 & 8.372 & $0.007^{*}$ \\
\hline ı. - Max. & \multicolumn{2}{|c|}{206.20 - 394.0} & & & & \\
\hline æn \pm SD. & \multicolumn{2}{|c|}{$265.55 \pm 80.19$} & & & & \\
\hline $\operatorname{dian}(\mathrm{IQR})$ & \multicolumn{2}{|c|}{$231.0(215.1-316.0)$} & & & & \\
\hline
\end{tabular}

$\mathrm{c}^{2}$ : Chi square test FE: Fisher Exact MC: Monte Carlot IQR: Inter-quartile range

t: Student t-test U: Mann Whitney test $\mathrm{p}$ : $\mathrm{p}$ value for comparing between the studied groups *: Statistically significant at $\mathrm{p} \leq 0.05$.

Table (2): Comparison between the two studied groups according to different microRNAs expression. 


\begin{tabular}{|c|c|c|c|c|}
\hline microRNAs expressions & $\begin{array}{l}\text { T1DM } \\
(n=90)\end{array}$ & $\begin{array}{l}\text { Control } \\
(\mathrm{n}=90)\end{array}$ & $\mathrm{U}$ & $P$ \\
\hline microRNA101-5p & & & \multirow{4}{*}{3652.0} & \multirow{4}{*}{$0.028^{*}$} \\
\hline Min. - Max. & $0.0-1640.55$ & $0.09-1.66$ & & \\
\hline Mean \pm SD & $65.33 \pm 270.39$ & $0.39 \pm 0.14$ & & \\
\hline Median (IQR) & $0.60(0.08-1.95)$ & $0.26(0.10-0.35)$ & & \\
\hline \multicolumn{5}{|l|}{ microRNA146a-5b } \\
\hline Min. - Max. & $0.0-328.49$ & $0.0-1.21$ & \multirow[t]{3}{*}{$2646.0^{*}$} & \multirow[t]{3}{*}{$<0.001^{\prime}$} \\
\hline Mean \pm SD & $7.89 \pm 48.63$ & $0.63 \pm 0.44$ & & \\
\hline Median (IQR) & $0.16(0.02-0.43)$ & $0.77(0.0-0.88)$ & & \\
\hline \multicolumn{5}{|l|}{ microRNA 375a-3p } \\
\hline Min. - Max. & $0.0-2127.09$ & $0.07-2.93$ & \multirow[t]{3}{*}{$1908.0^{*}$} & \multirow[t]{3}{*}{$<0.001^{*}$} \\
\hline Mean \pm SD & $70.36 \pm 332.53$ & $0.95 \pm 1.02$ & & \\
\hline Median (IQR) & $2.10(1.08-3.11)$ & $0.53(0.09-1.05)$ & & \\
\hline \multicolumn{5}{|l|}{ microRNA 21-3p } \\
\hline Min. - Max. & $0.0-89.39$ & $0.0-0.06$ & \multirow[t]{3}{*}{$2682.0^{*}$} & \multirow[t]{3}{*}{$<0.001^{\prime}$} \\
\hline Mean \pm SD & $2.27 \pm 13.21$ & $0.03 \pm 0.02$ & & \\
\hline Median (IQR) & $0.08(0.0-0.48)$ & $0.02(0.0-0.05)$ & & \\
\hline \multicolumn{5}{|l|}{ microRNA -126 } \\
\hline Min. - Max. & $0.00-0.62$ & $0.00-152.32$ & \multirow[t]{3}{*}{$1569.50^{*}$} & \multirow[t]{3}{*}{$<0.001^{*}$} \\
\hline Mean \pm SD & $0.19 \pm 0.15$ & $4.50 \pm 22.39$ & & \\
\hline Median (IQR) & $0.15(0.07-0.31)$ & $0.69(0.26-1.61)$ & & \\
\hline \multicolumn{5}{|l|}{ microRNA -Let 7a-5p } \\
\hline Min. - Max. & $0.0-35.80$ & $0.0-1.92$ & \multirow[t]{3}{*}{$2356.50^{*}$} & \multirow[t]{3}{*}{$<0.001^{*}$} \\
\hline Mean \pm SD & $0.94 \pm 5.21$ & $0.50 \pm 0.51$ & & \\
\hline Median (IQR) & $0.09(0.02-0.23)$ & $0.12(0.10-1.02)$ & & \\
\hline
\end{tabular}

U: Mann Whitney test $\mathrm{p}$ : $\mathrm{p}$ value for comparing between the studied groups *: Statistically significant at $\mathrm{p} \leq 0.05$

Table (3): Correlation between different parameters and all microRNAs in patients with T1D. 


\begin{tabular}{|c|c|c|c|c|c|c|c|}
\hline & & $\begin{array}{l}\text { microRNA } \\
101-5 p\end{array}$ & $\begin{array}{l}\text { microRNA } \\
146 a-5 b\end{array}$ & $\begin{array}{l}\text { microRNA } \\
375 a-5 p\end{array}$ & $\begin{array}{l}\text { microRNA } \\
21-3 p\end{array}$ & \begin{tabular}{|l|} 
microRNA \\
-126
\end{tabular} & $\begin{array}{l}\text { microRNA -Let } \\
7 a-5 p\end{array}$ \\
\hline $\begin{array}{l}\text { Duration of } \\
\text { illness }\end{array}$ & $\begin{array}{l}\mathrm{r}_{\mathrm{s}} \\
\mathrm{P}\end{array}$ & $\begin{array}{l}-0.162 \\
0.02^{*}\end{array}$ & $\begin{array}{l}0.239 \\
0.023^{*}\end{array}$ & $\begin{array}{l}0.095 \\
0.386\end{array}$ & $\begin{array}{l}-0.151 \\
0.167\end{array}$ & $\begin{array}{l}-0.167 \\
0.128\end{array}$ & $\begin{array}{l}-0.034 \\
0.756\end{array}$ \\
\hline Age of onset & $\mathrm{r}_{\mathrm{s}}$ & $\begin{array}{l}-0.264 \\
0.015^{*}\end{array}$ & $\begin{array}{l}0.149 \\
0.160\end{array}$ & $\begin{array}{l}-0.008 \\
0.943\end{array}$ & $\begin{array}{l}0.211^{*} \\
0.046^{*}\end{array}$ & $\begin{array}{l}0.089 \\
0.402\end{array}$ & $\begin{array}{l}-0.062 \\
0.563\end{array}$ \\
\hline HbA1c & $\mathrm{r}_{\mathrm{s}}$ & $\begin{array}{l}0.090 \\
0.413 \\
\end{array}$ & $\begin{array}{l}0.183 \\
0.162 \\
\end{array}$ & $\begin{array}{l}0.173 \\
0.201\end{array}$ & $\begin{array}{l}0.054 \\
0.610 \\
\end{array}$ & $\begin{array}{l}-0.214 \\
0.042^{*} \\
\end{array}$ & $\begin{array}{l}-0.216 \\
0.043^{*} \\
\end{array}$ \\
\hline FBS & $\begin{array}{l}\mathrm{r}_{\mathrm{s}} \\
\mathrm{P}\end{array}$ & $\begin{array}{l}-0.194 \\
0.067\end{array}$ & $\begin{array}{l}0.176 \\
0.097\end{array}$ & $\begin{array}{l}-0.147 \\
0.166\end{array}$ & $\begin{array}{l}0.166 \\
0.119\end{array}$ & $\begin{array}{l}-0.032 \\
0.764\end{array}$ & $\begin{array}{l}0.241 \\
0.022\end{array}$ \\
\hline $2 \mathrm{hr} p \mathrm{p}$ & $\begin{array}{l}\mathrm{r}_{\mathrm{s}} \\
\mathrm{P}\end{array}$ & $\begin{array}{l}-0.215 \\
0.042\end{array}$ & $\begin{array}{l}0.134 \\
0.209\end{array}$ & $\begin{array}{l}-0.008 \\
0.939\end{array}$ & $\begin{array}{l}0.096 \\
0.368\end{array}$ & $\begin{array}{l}0.006 \\
0.954\end{array}$ & $\begin{array}{l}0.123 \\
0.247\end{array}$ \\
\hline
\end{tabular}

$\mathrm{r}_{\mathrm{s}}$ : Spearman coefficient $*$ : Statistically significant at $\mathrm{p} \leq 0.05$

Table (4): Univariate and multivariate analysis for the parameters affecting T1DM risk (No. $=90)$

\begin{tabular}{|l|l|l|l|l||}
\hline \hline & \multicolumn{2}{|l|}{ Univariate } & \multicolumn{2}{l||}{ Adjust Odd`s ratio } \\
\cline { 2 - 5 } & $\mathbf{P}$ & COR (95\%C.I) & $\mathbf{p}$ & AOR $^{\#}$ (95\%C.I) \\
\hline microRNA 101-5p & $\mathbf{0 . 0 0 9 ^ { * }}$ & $1.565(1.121-2.185)$ & 0.307 & $1.783(0.587-5.414)$ \\
\hline microRNA 146a-5p & $\mathbf{0 . 6 1 6}$ & $1.017(0.951-1.088)$ & 0.844 & $1.009(0.924-1.101)$ \\
\hline microRNA Let 7 a-5p & $<0.001^{*}$ & $1.845(1.370-2.483)$ & $0.048^{*}$ & $1.808(1.006-3.249)$ \\
\hline microRNA 21-5p & $<0.001^{*}$ & $11.62(3.63 .69-71.85)$ & $0.026^{*}$ & $7.180(2.554-20.187)$ \\
\hline microRNA -126 & $<0.001^{*}$ & $0.013(0.002-0.064)$ & $0.021^{*}$ & $0.016(0.0-0.544)$ \\
\hline microRNA -375 & $\mathbf{0 . 4 5 3}$ & $1.037(0.943-1.140)$ & 0.921 & $1.014(0.776-1.324)$ \\
\hline \hline
\end{tabular}

OR: Odd`s ratio,

C.I: Confidence interval, $\mathrm{AOR}^{\#}$ : adjust Odd`s ratio by family history and HbA1C 
*: Statistically significant at $\mathrm{p} \leq 0.05$.

Figures

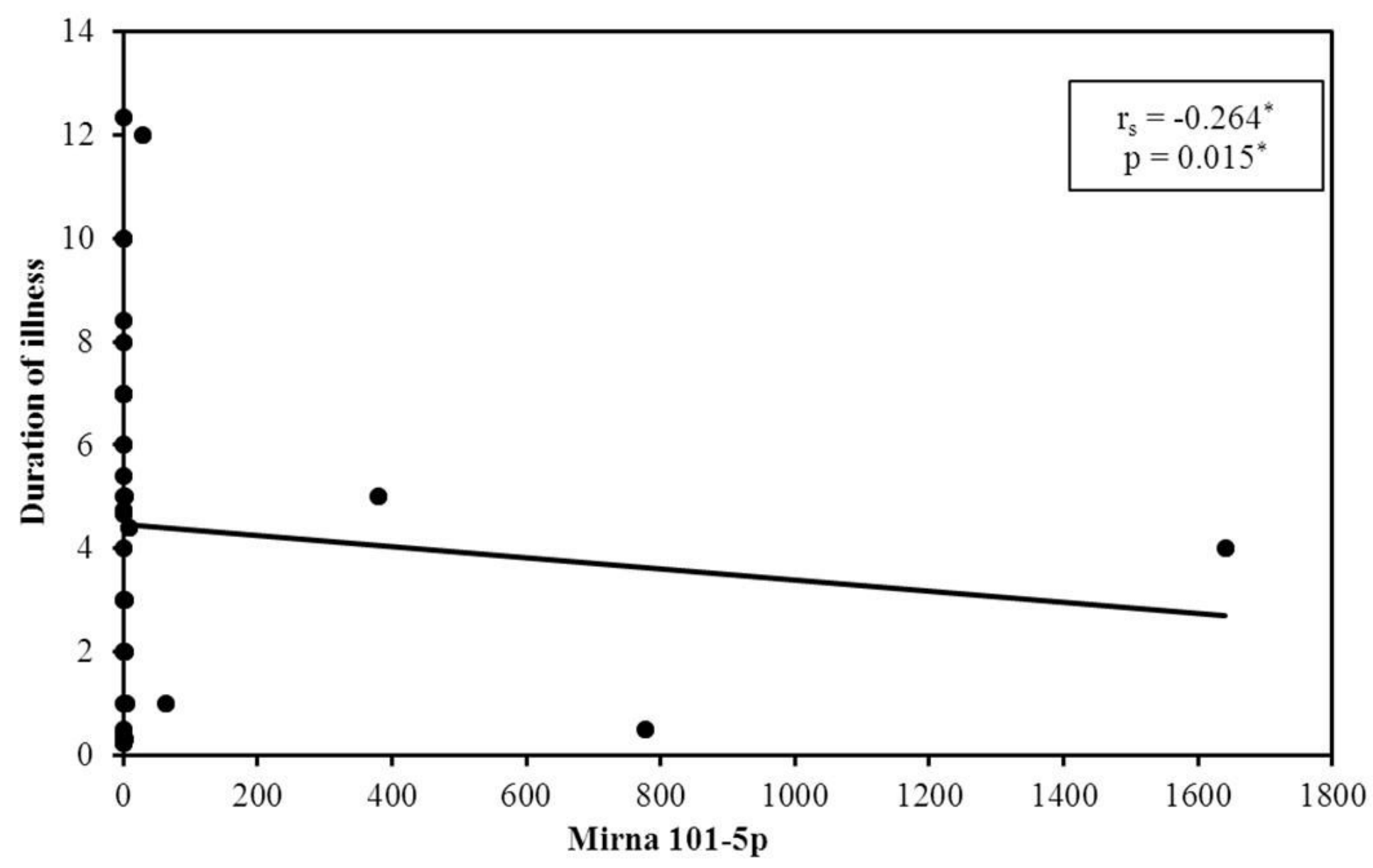

Figure 1

Correlation results between microRNA 101-5p with age of T1D onset. 


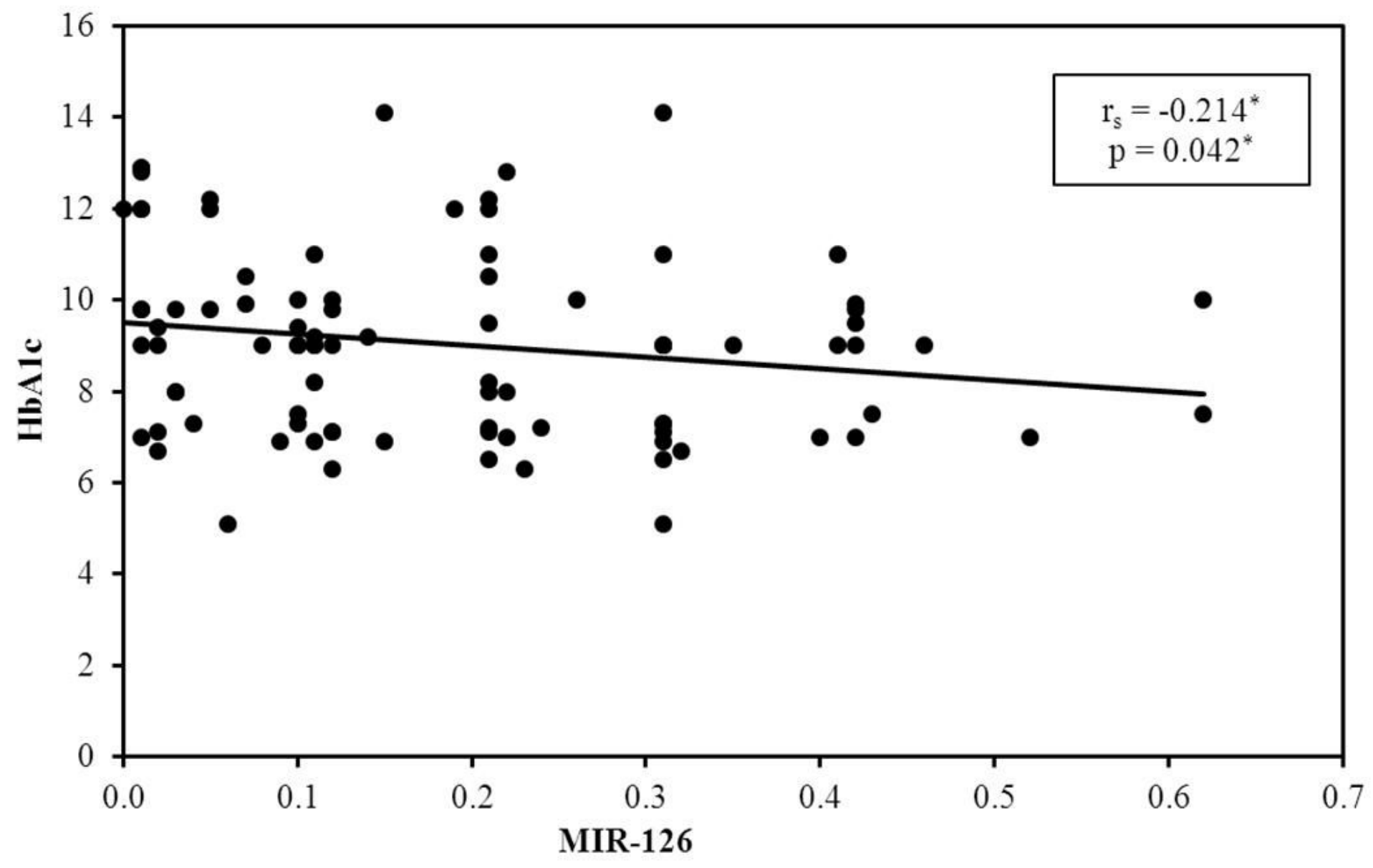

Figure 2

Correlation results between microRNA -126 and $\mathrm{HbA} 1 \mathrm{c}$. 


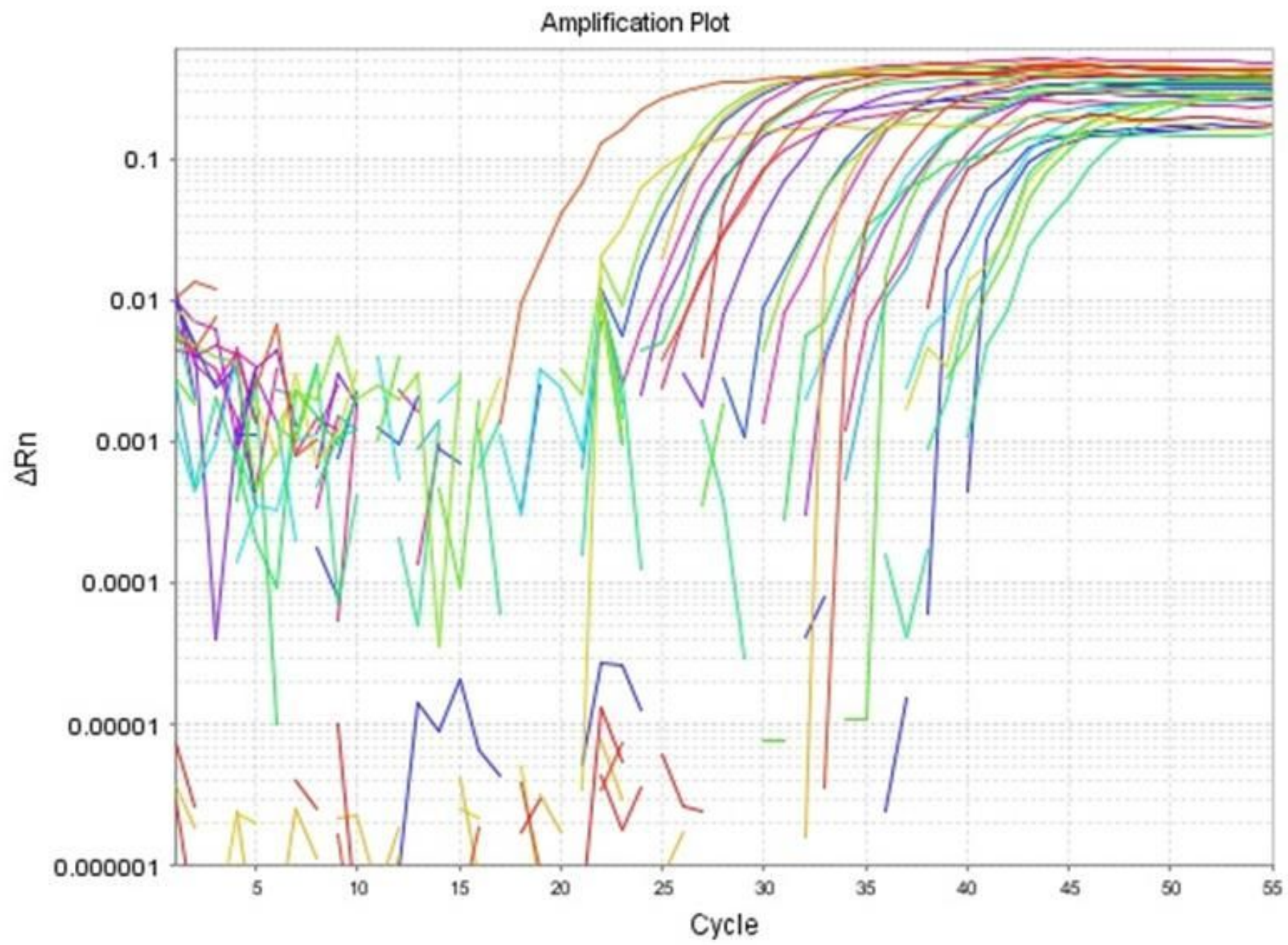

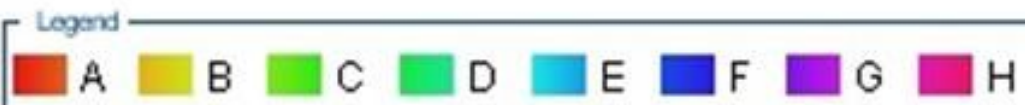

Figure 3

Amplification plot for mi RNA 21-5p expression pattern (normalized fluorescent signal [ $\Delta$ Rn] plotted against the number of the cycle).

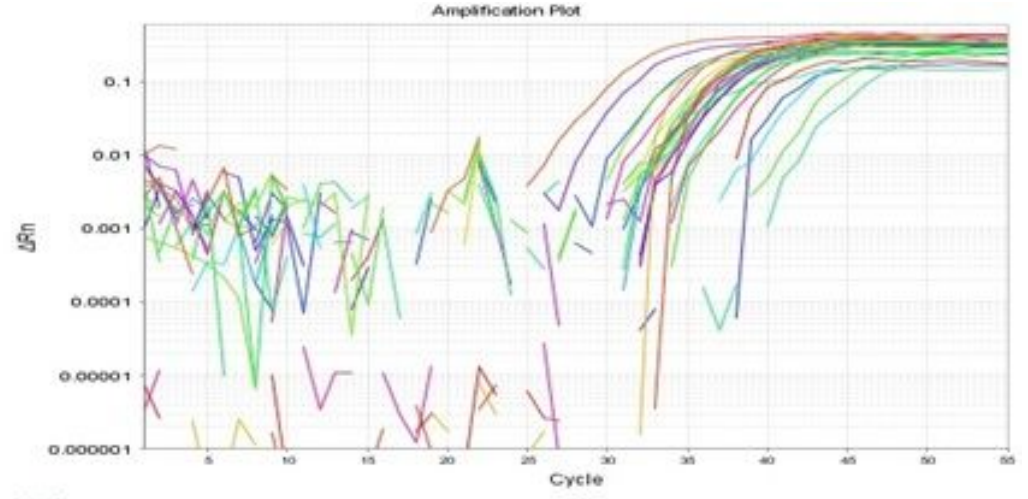

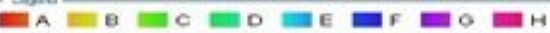


Figure 4

Amplification for mi RNA 101-5p expression (normalized fluorescent signal [ $\Delta \mathrm{Rn}]$ plotted against the number of the cycle).

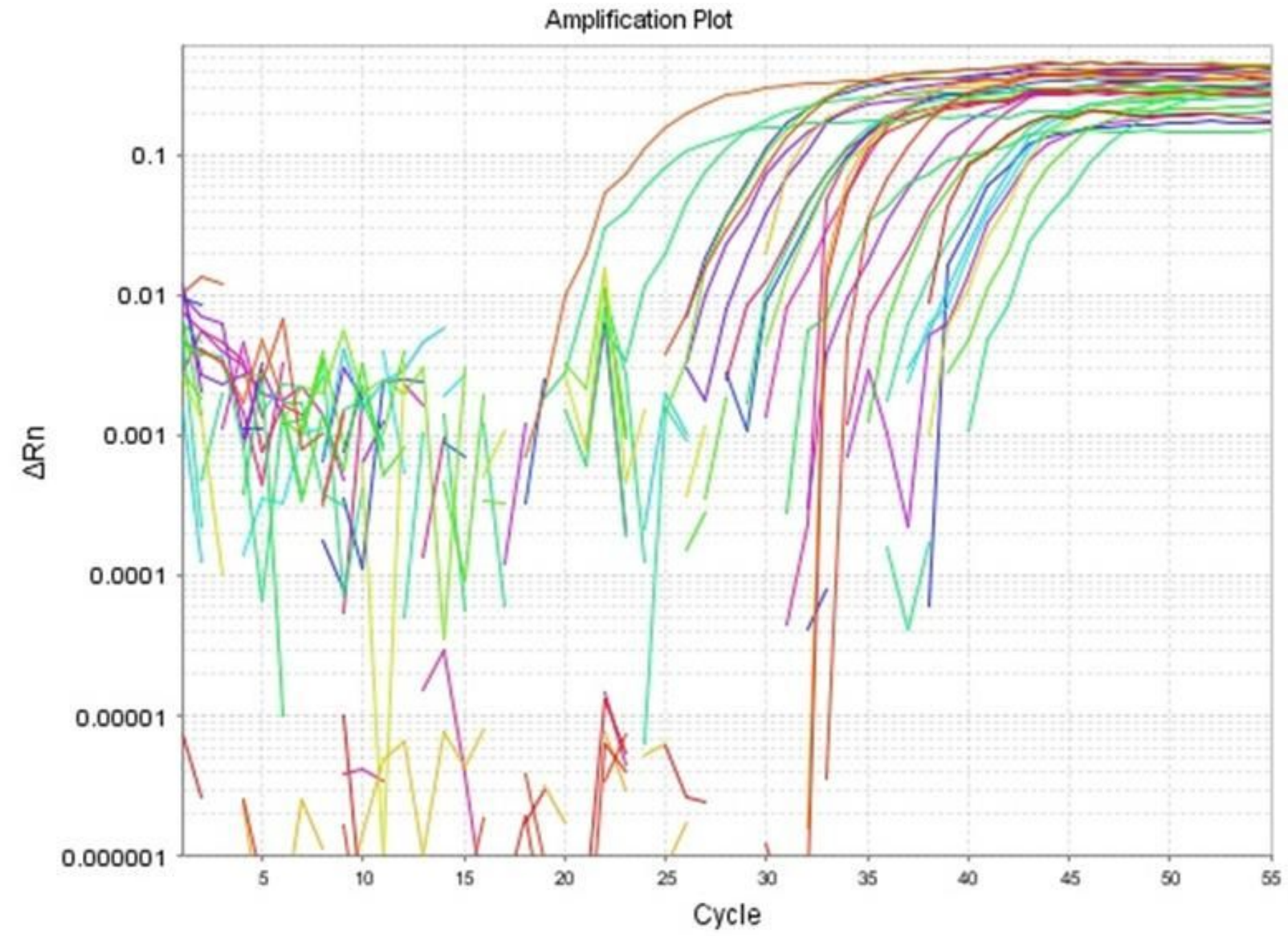

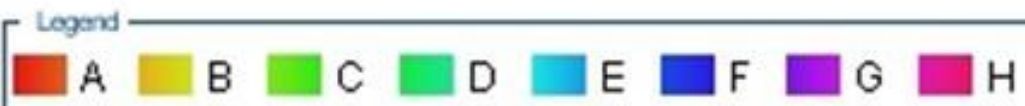

Figure 5

Amplification for mi RNA 146a-5p expression (normalized fluorescent signal [ $\Delta \mathrm{Rn}]$ plotted against the number of the cycle). 


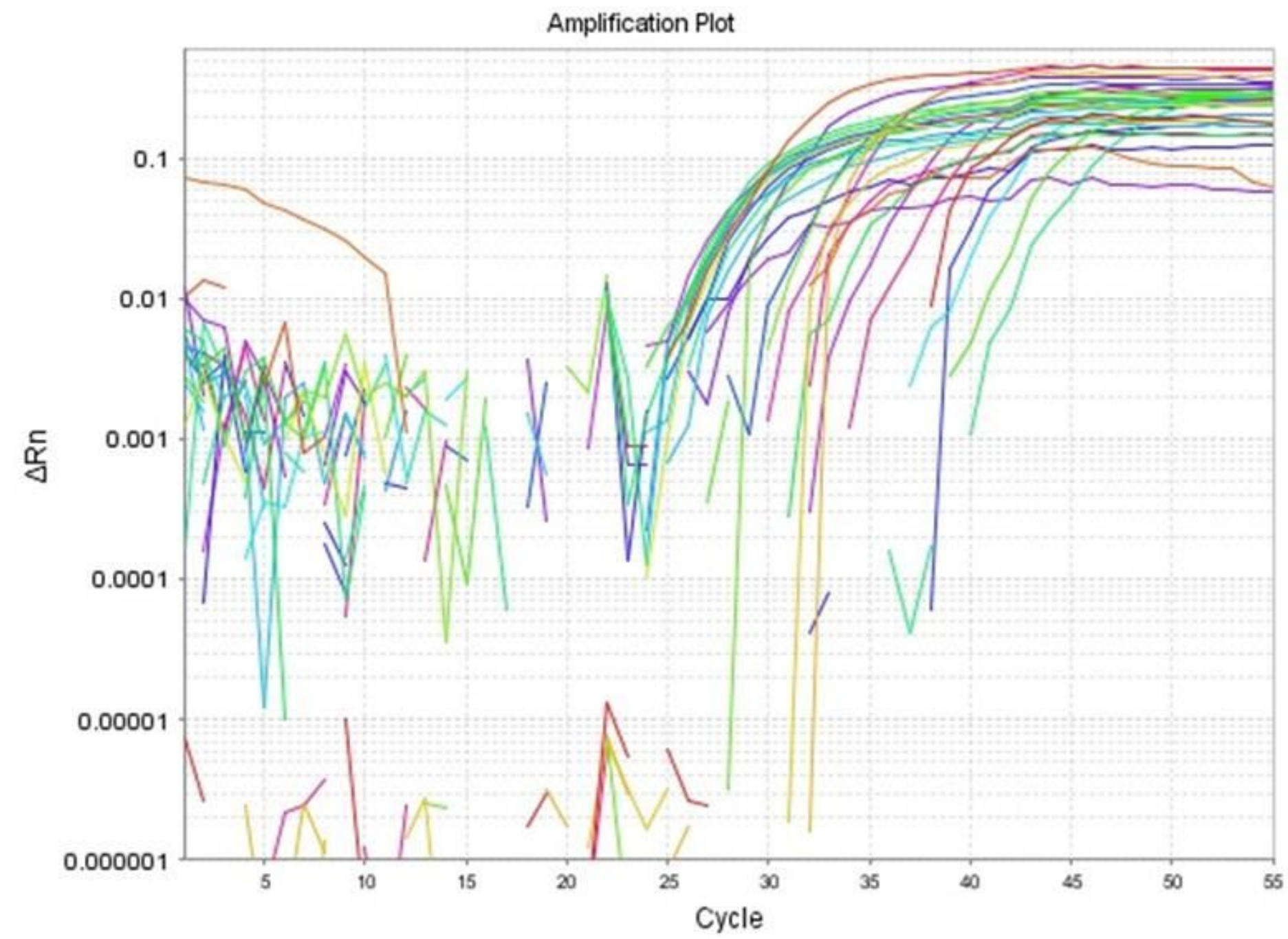

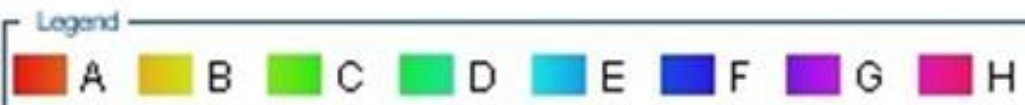

Figure 6

Amplification for mi RNA- 375 expression (normalized fluorescent signal $[\Delta \mathrm{Rn}]$ plotted against the number of the cycle). 


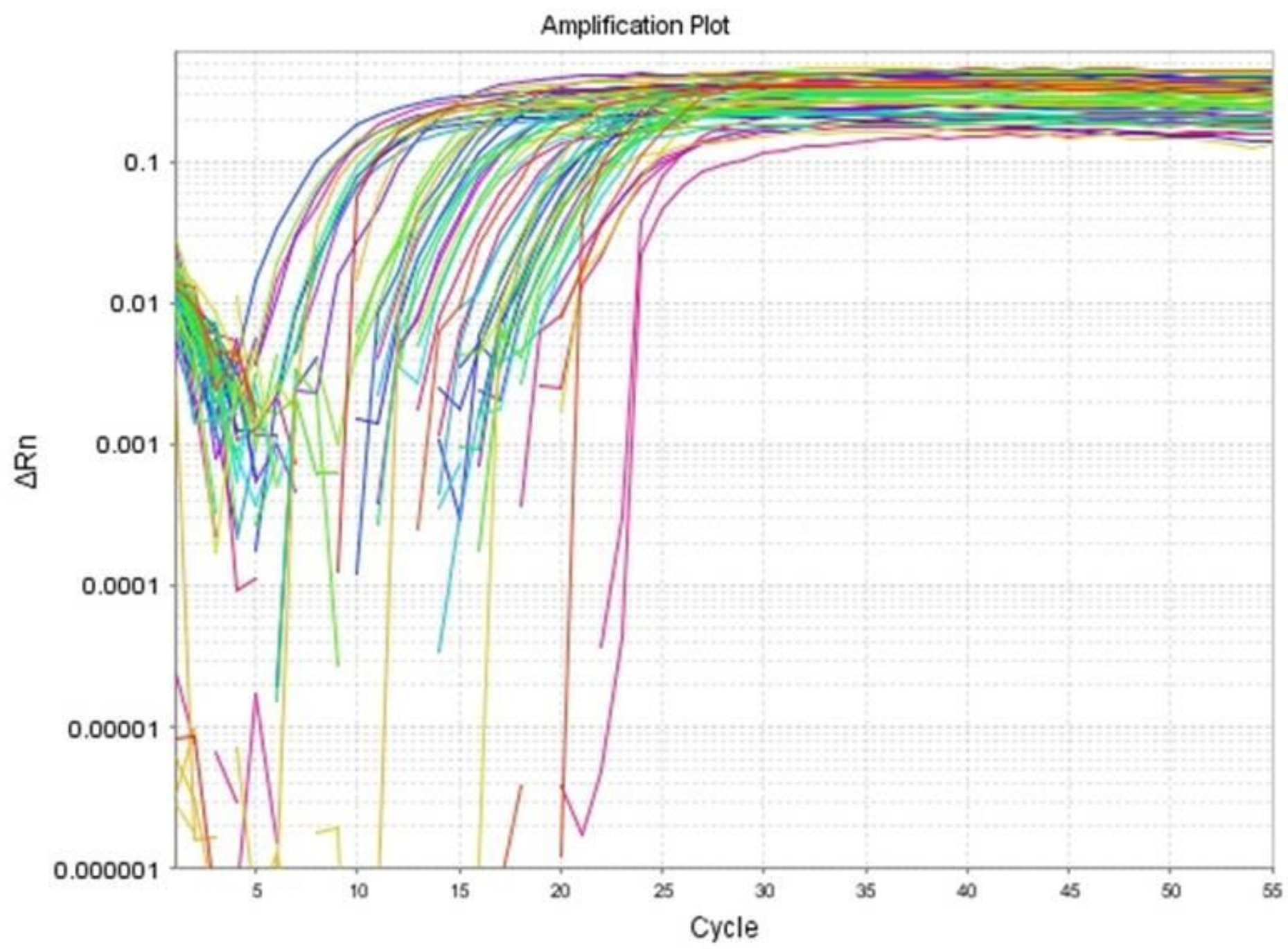

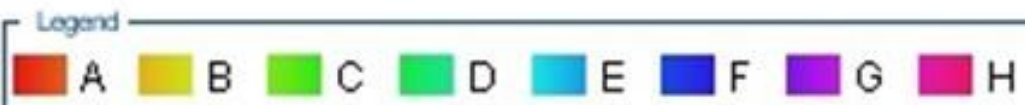

Figure 7

Amplification plot of miR Let 7 a-5p expression (normalized fluorescent signal $[\Delta R n]$ against the number of the cycle). 


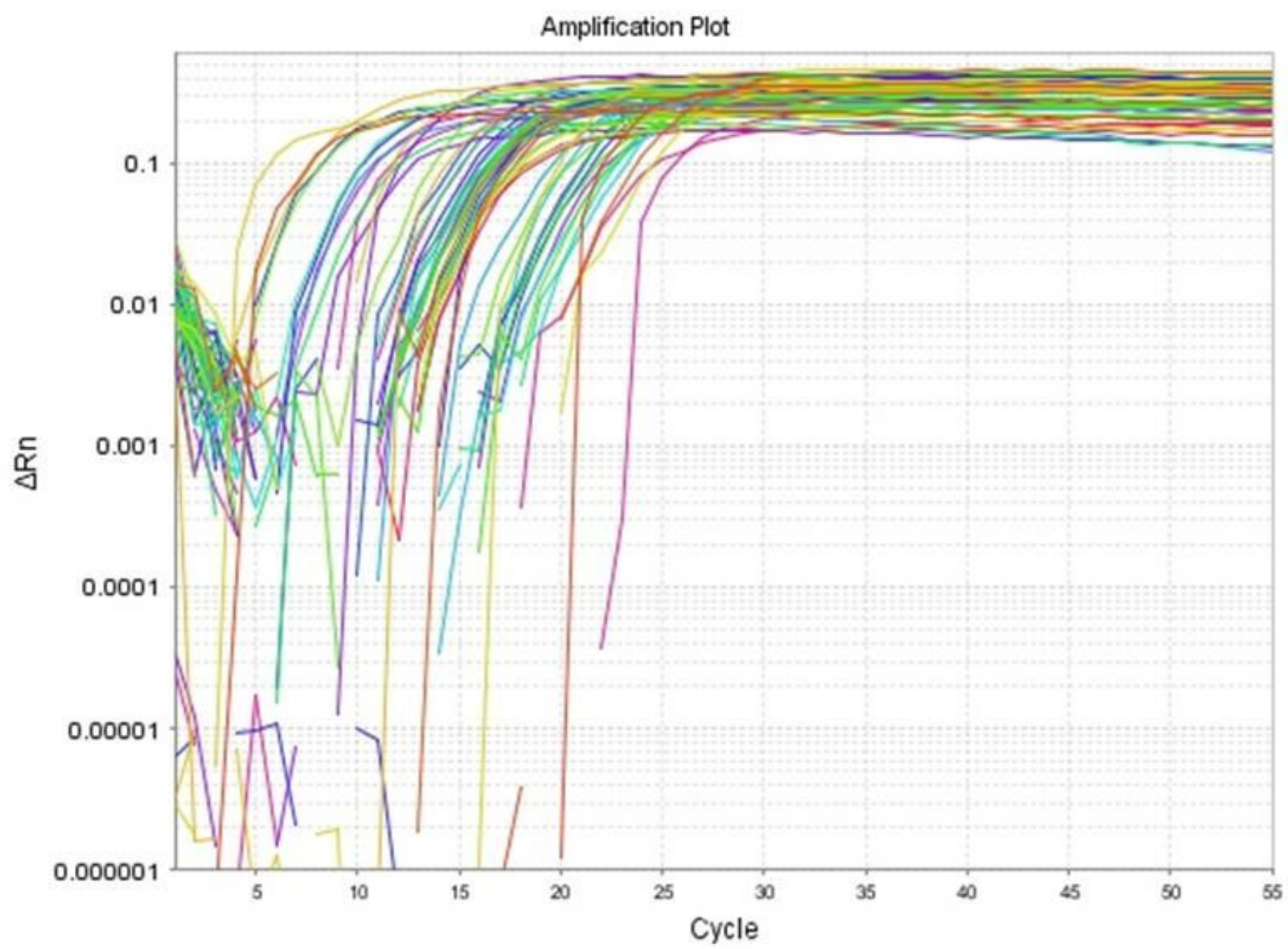

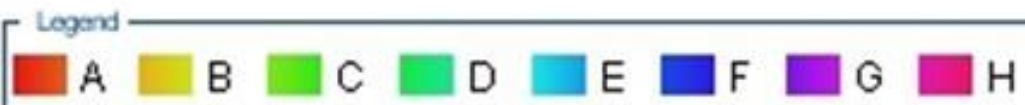

Figure 8

Amplification of miR 126 gene expression (normalized fluorescent signal [ $\Delta \mathrm{Rn}]$ against the number of the cycle). 